\title{
The Home-School Linkage Instructional System and Its Development Suggestions Under the Perspective of Large-Scale Home-Based Learning
}

\author{
Fei Shang, Yang Xing* \\ Beijing Normal University, 100875 Beijing, China.
}

\begin{abstract}
How to cite this paper: Fei Shang, Yang Xing. (2021). The Home-School Linkage Instructional System and Its Development Suggestions Under the Perspective of Large-Scale Home-Based Learning. The Educational Review, USA, 5(7), 232-244. DOI: 10.26855/er.2021.07.007
\end{abstract}

Received: May 31, 2021

Accepted: June 28, 2021

Published: July 30, 2021

Corresponding author: Yang Xing, Beijing Normal University, 100875 Beijing, China.

Email: xywzy468129@163.com

\begin{abstract}
The learning ecosystem is the unified whole formed by education and its surrounding environment, including human elements such as the internal school education system and organization and non-human factors such as the external soft and challenging environment. However, the global COVID-19 outbreak in 2020 has led to large-scale home-based learning among students, which has broken the original ecological balance of learning. The interaction between the four elements of the traditional instructional system cannot explain all the teaching behavior. Based on the research perspective of large-scale home-based learning, this paper proposes to add family and technology into the original teaching system framework to form a new family-school linkage instructional System framework, including school education, family education, online teaching, and other types of education, improve the learning ecosystem and provide new thinking for the education and teaching in the post-epidemic era.
\end{abstract}

\section{Keywords}

Instructional System, Home-based learning, Home education, Educational Technology

\section{Introduction}

Learning ecosystems are the unified whole formed by education and its surrounding environment, including human elements such as internal school education system and organization and non-human factors such as the external soft and challenging environment. The concept of a learning ecosystem effectively helps communicate how learning happens across space and time as a dynamic process of interaction between a host of elements (Hecht, 2020). It is open self-organization and self-adaptive structural system, capable of self-adjustment through the behavior of the subject, and has a certain intelligence (Wu, 2015). The research on the ecology of learning in mainland China began in the 1980s but developed slowly. It was not until the early 21st century that relevant studies gradually enriched, from macro to micro, from theoretical discussion to practical analysis. Throughout the 30 years of research, we can find that the ecology of learning still has many weak links. There is not enough understanding of the importance of the learning ecosystem, not enough attention to the analysis of the historical changes of the learning ecology, not enough accurate grasp of the ecological principles, and not enough balance in the study of the level and structure of the learning ecology (Deng, 2009). The ecological problems of learning in China are gradually emerging, and the research object of the ecology of learning needs to be further established.

With the COVID-19 outbreak in 2020, primary and middle school students across the country are forced to study at 
home. The home-based online learning in primary and secondary schools during the epidemic period is a student-centered teaching method very different from the traditional face-to-face synchronous teaching in classes. It should conform to the fundamental characteristics of "separation of teaching and learning, time-space separation and teacher-student (student-student separation)" shared by all distance education (Liang, 2020). The original ecological balance of teaching is broken, resulting in many problems. The teaching form has changed, and parents' participation in their children's study and life has greatly increased. The interaction between the four elements of the traditional instructional system is no longer sufficient to explain all teaching behaviors. Teachers' professional skills in information technology need to be improved, and their emphasis on home education needs to be improved. Although the great change of teaching form is due to the need of the situation, with the advancement of the digital process of schools, online teaching may promote the lasting digital transformation of higher education [3], and home-based learning has become a normal form of education in basic education. It is necessary to analyze and reconstruct the instructional system under the home-based learning environment and add the family and technology into the framework of the new instructional system.

\section{Challenges and Opportunities for Home-Based Learning}

The situation that a large number of students in China are forced to study at home has drawn the close attention of many experts in the field of education, and many activities have been organized and discussed. It is generally recognized that home-based learning on such a large scale in China today is a coexistence of challenges and opportunities for students, teachers, parents, and schools. Despite many difficulties, it is also an opportunity to generate new teaching methods and provide new options for the integration of teaching and learning models in the future.

\subsection{Challenges of Home-Based Learning}

In the process of home-based learning, teachers need to re-recognize their instructional goal, teaching content, and teaching methods, and use the shortest time to improve their professional skills in online teaching. The change in the teaching environment has brought about tremendous changes in the way students attend class (Clary Torres, 2020). Students' physical and mental health will be significantly affected if they sit in front of electronic devices for a long time. Parents play the role of who participating in the daily work of preparing homework and helping their children with homework. Due to the lack of teaching experience, parents are faced with many problems in education and teaching. For example, they do not know the teaching methods and cannot let their children master the subject knowledge correctly. Moreover, parents' long-term supervision of students is also likely to cause their children to have a rebellious mentality.

In an online classroom, the interaction between teaching and learning, the openness of teaching process, and students' participation in the course have all changed. There are few online classroom practice cases, a lack of corresponding evaluation criteria, and no complete system model. At present, the construction of online teaching resources in our country is seriously insufficient. The infrastructure construction is not complete, so we do not have the conditions for large-scale online teaching. In remote and poor areas, students do not have even the most basic online learning tools, such as mobile phones, and even fewer have laptops.

\subsection{Opportunities for Home-Based Learning}

Although China has some ideas to launch online teaching research, and has achieved a series of achievements such as classroom in the air and building digital schools, there are still a lot of problems in the field of online teaching that need to be further studied. This epidemic provides a good opportunity for this. This large-scale home-based learning activity is a test of teachers' information teaching ability, and also a good opportunity to improve their own teaching ability, including teachers' teaching implementation ability, teaching design ability, teaching evaluation ability and so on. Teachers can learn online learning resources that are hard to get access to in their daily teaching life, study excellent teaching cases, learn from each other and apply them to their own teaching practice. The main problem that teachers organize online learning is not the presentation of content, but how to organize high-quality teaching content more rationally to promote the occurrence of learning (Yu, 2020).

The monitoring degree of teachers in on-line teaching is far lower than that in off-line teaching, which is mainly to cultivate students' autonomous learning ability. In the field of science education, teachers can seize the opportunity to lead students to do science education topics related to the epidemic, improve students' scientific literacy, cultivate students' scientific thinking of scientific observation and research, and generate persuasive scientific research conclusions.

Relevant education departments of the state have realized the need to increase investment in education resources, improve infrastructure construction, increase training for teachers, especially pay more attention to the education situation in poor and remote rural areas, promote educational equity, and provide basic hardware facilities. 
Children's long-term home life has greatly increased their time with their parents, enhanced their understanding of each other, and is a good opportunity to carry out family education. In family life, parents, as the main body of family education, cultivate children's love of life and independent character. To complete scientific experiments together with children and encourage them to practice and innovate more, China is in the stage of transformation, and talents with the consciousness of labor innovation are in great need. Family education should be combined with school education so that students can develop morally, intellectually, and physically more comprehensively.

\section{Concepts and Paradigms of Home-Based Learning}

\subsection{Concept of Home-Based Learning}

"Home-based learning" was originally by the executive director of education of China policy institute at Beijing Normal University, Professor Zhang Zhiyong on February 5, 2020, focusing on emphasis on the change of learning environment, students' learning place back home from school, breaks through the traditional school education form and become a kind of combination of family education, school education and social education of new education form (2020). Song Shuqiang believes that home-based learning is guided by parents or several families to complete the basic learning work at home. Gao Shuguo differentiate from a conceptual point of view, believes that home-based study has a double meaning. On the one hand, refers to the individual learners as the main body of the selectivity of self-learning at home, generally is the informal learning that studies at home, on the other hand is the individual learners' learning at home through TV, Internet and other media formal school curriculum (including review), known as the formal learning that study at home. Home-based learning is a kind of collective learning organized by network, school, class group and individual diversity. It is a learning activity that lives at home to complete the regular school curriculum arrangement and achieve the educational and teaching goals (Gao, 2020).

\subsection{Paradigms of Home-based Learning}

According to Professor Zhang Zhiyong, home-based learning is not only simple online teaching, but also includes a variety of learning forms. First, students study independently at home in a complete sense; second, teacher-led self-study and online teaching activities; third, family literacy activities; fourth, online education and learning outside the school (2020). Song Lingqing classified students' home-based learning into eight types according to whether teachers have guiding ability, whether online learning depends on teachers and students' educational information conditions and information literacy, and whether autonomous learning depends on students' self-learning willingness and self-learning ability. Online autonomous learning under the guidance of teachers, teachers' guidance of offline autonomous learning, online autonomous learning under the guidance of teachers, teachers' guidance of offline passive learning, online passive learning under the guidance of teachers, teachers guide line passive learning, no passive online learning under the guidance of teachers, and no offline passive learning under the guidance of teachers (Song, 2020) .

\section{The Difference between Home Study and Campus Study}

\subsection{Teachers}

In the traditional campus learning life, teachers and students implement face-to-face teaching, which can monitor students' learning situation at any time, grasp the course progress and timely intervene to ensure the achievement of teaching goals. Moreover, based on the accumulation of a large number of previous teaching experience, teachers are flexible in teaching. In the home-based learning stage, teachers cannot fully monitor the learning process. If they want to know the learning progress of students in class, they need to have continuous interaction with students. Students' off-line free time is increased and teachers' guidance is lacking, so students should be encouraged to study independently. In terms of teachers' skills, due to the lack of online teaching practice opportunities, teachers' insufficient information technology ability and difficulty in dealing with emergent problems, teachers generally report that they lack confidence in teaching. In order to achieve the teaching objectives, teachers and parents should actively contact, cooperate with each other, and jointly monitor the students’ learning status and progress.

\subsection{Students}

When students in primary and secondary school carry out online learning, their learning motivation is insufficient, and their self-directed learning ability is weak, especially in the lower grades. Students in the upper grades cannot resist the temptation of electronic devices and cannot pay attention in class. The lack of learning partners makes students less motivated to learn, unable to timely communicate with teachers and classmates when encountering academic problems, 
and their academic progress is slow. Campus learning is convenient for students to develop regular life and rest and study habits. Students can supervise each other to promote students' learning initiative, and homework problems can be solved by timely asking teachers.

Studying at home also gives students a lot of opportunities to improve their life skills. It is a good time for students to experience family literacy. Students help their parents to do some housework within their power at home, and set up a correct outlook on life, world outlook and values under the education of their parents, so as to ease the family atmosphere. At home, students can also read a lot of extracurricular resources to increase their knowledge reserves in various aspects.

\subsection{Teaching Content}

Compared with traditional campus learning, home-based learning is rich in a variety of learning forms, and the teaching content has changed from single teaching materials to diversified knowledge transmission. The teachers of students can be "school teachers", "parents of students" and "students themselves". Family education is closely integrated with campus education, and teachers carry out relevant research in combination with the real living environment at home, such as analyzing the development status of the global epidemic and estimating its trend, so as to guide students to practice and improve their own level in the real situation. Family education fosters the formation and development of students' moral, intellectual, physical and aesthetic qualities, especially the formation and development of children's ideological morality and personality. Combining with the phenomenon that most children are unwilling to work, unable to work, and do not cherish the fruits of labor, labor education should be integrated into family education to cultivate children's labor awareness and attitude towards life, and develop good working habits. Scientific research shows that the improvement of labor skills is conducive to improving people's ability of practical innovation. Home-based learning can not only expand the content taught in schools but also supplement and cultivate children according to the characteristics of families.

\subsection{Instructional Media}

Students will use mobile phones, laptops, and other multimedia mobile devices for online learning, and complete the tasks of teacher-student interaction and student interaction with the help of multiple network platforms such as "Tencent Conference" and "cloud video conferencing". Students have more diverse access to information, not only from textbooks, but also from electronic devices such as televisions and recorders. In the campus learning, the teaching media is relatively single, with books as the main teaching material and teachers' multimedia courseware as the auxiliary.

\subsection{Family}

Families in the home and campus learning contrast is the difference between the highest element, in the campus learning, parents usually just provide basic economic security for the students' campus life, and for the children learn responsibility division of labor is less, most parents, usually with the teachers in the teacher in charge have parents or individual contact to understand students' learning situation. In home-based learning, parents play the role of "education administrator", the leader of family education and the coordinator of school education, and promote students' all-round development in all aspects. We will strive to understand families as complex, interactive systems where parents have the primary responsibility as educators, nurturers, and limit-setters for children (Palm, 1999). Students in the lower grades have low cognitive ability and poor self-directed learning ability. Parents need to provide electronic devices for their children's study and also help them with their schoolwork. For senior students, faced with heavy academic pressure, parents should not only care about their children's learning effect but also do a good job in logistical support work to maintain their children's life and health (Xiao, 2020).

\subsection{Technology}

Network technology is also used in traditional campus learning, but it does not play a decisive role in the teaching process. Teachers mainly teach in the classroom based on their own teaching experience. In the three learning forms of "teacher-led self-learning and online teaching activities", "student-led learning in a complete sense", and "online educational learning outside the school", network technology plays a supporting role. Both the school and the students need to use the network teaching platform system to interact, teachers upload courseware, students complete the task, the platform will record the teaching process and students' learning behavior, the final online assessment also depends on the network technology guarantee. 


\section{Survey on the Influence of Home-Based Learning on Students}

In the context of the COVID-19 epidemic, China is in the reality of large-scale home-based learning. Technology has become the supporting factor of online learning, and family has also become an indispensable part of students' home-based learning. The following will introduce the investigation process and results of the home-based study questionnaire survey.

\subsection{Survey Design}

Survey object. This study selected Botou City, Hebei Province, China, the fourth middle school (junior high school), the first secondary school (high school) of Botou city, Si Mencun elementary school, and junior high school teachers, parents and the students as the research object, adopt the network questionnaire survey (questionnaire star), and received 242 effective questionnaires were teachers, students and effective questionnaire 657, 528 effective questionnaires were parents. The teacher-student ratio is relatively reasonable. As an important variable of the teaching system under the condition of home-based learning, parents can reflect the role of family in home-based learning, and the number is also basically reasonable. As the subject of study, students can reflect their real thoughts during the period of home-based learning. On the whole, the number of samples and the distribution of institutions of research data are relatively reasonable.

The dimension of the questionnaire. Parents questionnaire mainly focuses on the role of parents in the learning environment that study at home, education behavior and its effect, the student questionnaire tend to interview students for the study of subjective view that study at home, learning state, learning effect, etc., teacher questionnaire focusing on interviews with teachers and parents of the communication situation, teachers' teaching methods and so on. Table 1 , Table 2 and Table 3 below are the dimensions of a student questionnaire, parent questionnaire and teacher questionnaire respectively.

Table 1. Dimensions of the student questionnaire

\begin{tabular}{|c|c|c|}
\hline Dimensions & Explanation & Question number \\
\hline Basic information & Phase of studying & 1 \\
\hline $\begin{array}{l}\text { Investigation on teaching methods of teachers during } \\
\text { the COVID-19 outbreak }\end{array}$ & Tools and methods of online learning; & $2,3,4$ \\
\hline Self-regulation of learning & $\begin{array}{l}\text { Complete homework and attend classes indepen- } \\
\text { dently }\end{array}$ & 5,6 \\
\hline The importance of parents in the teaching system & $\begin{array}{l}\text { Conflicts arise because of learning; family rela- } \\
\text { tionships affect online learning; and other inter- } \\
\text { ests in addition to learning are cultivated; }\end{array}$ & $7,8,10$ \\
\hline Evaluate the effect of home-based learning & $\begin{array}{l}\text { The effects of online courses; A life skills as- } \\
\text { sessment; }\end{array}$ & 9,11 \\
\hline
\end{tabular}

Table 2. Dimensions of the parent questionnaire

\begin{tabular}{|c|c|c|}
\hline Dimensions & Explanation & Question number \\
\hline Basic information & $\begin{array}{c}\text { Career; education background, the number of children who need to learn } \\
\text { online, child’s grade level }\end{array}$ & $1,2,3,4$ \\
\hline $\begin{array}{l}\text { Children's autonomy in } \\
\text { learning }\end{array}$ & $\begin{array}{l}\text { During the COVID-19 outbreak, parents observed and evaluated their } \\
\text { children's attendance at school, completion of homework and study plans }\end{array}$ & $6,7,8,11$ \\
\hline $\begin{array}{l}\text { Online Learning Com- } \\
\text { munity (Parent-student) }\end{array}$ & $\begin{array}{l}\text { Parents' supervision and guidance of students' learning and its effect. } \\
\text { Conflicts between parents and children due to online learning }\end{array}$ & $9,10,15,16,17$ \\
\hline $\begin{array}{l}\text { The development of fam- } \\
\text { ily education }\end{array}$ & $\begin{array}{c}\text { Parents’ attitude towards students’ other abilities under home-based } \\
\text { learning }\end{array}$ & $12,13,14$ \\
\hline $\begin{array}{l}\text { Learning Community } \\
\text { (Parent-teacher) }\end{array}$ & $\begin{array}{l}\text { The degree of cooperation between parents and teachers, the frequency of } \\
\text { communication between parents and teachers }\end{array}$ & 19,20 \\
\hline $\begin{array}{l}\text { Teaching quality evalua- } \\
\text { tion }\end{array}$ & $\begin{array}{c}\text { Parents' recognition of home-school communication, parents' evaluation } \\
\text { of children’s learning outcomes }\end{array}$ & 18,21 \\
\hline
\end{tabular}


Table 3. Dimensions of the teacher questionnaire

\begin{tabular}{|c|c|c|}
\hline Dimensions & Explanation & $\begin{array}{l}\text { Question num- } \\
\text { ber }\end{array}$ \\
\hline Basic information & Education background; teaching age; Teaching grade & $1,2,3$ \\
\hline $\begin{array}{l}\text { Learning Community } \\
\text { (Teacher-Parent) }\end{array}$ & $\begin{array}{l}\text { The communication frequency between teachers and parents; the communica- } \\
\text { tion frequency between parents and teachers; the cooperation degree of parents }\end{array}$ & $4,5,6,7,8,9$ \\
\hline $\begin{array}{l}\text { The innovation of teaching } \\
\text { methods }\end{array}$ & $\begin{array}{l}\text { The innovation of teaching methods and the interaction between teachers and } \\
\text { students during the COVID-19 outbreak }\end{array}$ & 10,11 \\
\hline Self-regulation of learning & Teachers' evaluation of students' autonomy in learning & 12 \\
\hline
\end{tabular}

Research tool. The data involved in this study were input, sorted out and statistically analyzed using Excel and SPSS data statistics software.

\subsection{Data Analysis}

Through Spearman's rank correlation test and descriptive statistics of the questionnaire, it is found that the family atmosphere is significantly correlated with students' home-based learning effect, and parents' ability cultivation in other aspects besides learning is significantly positively correlated with students' home-based learning effect. Family has a significant influence on students' home-based learning.

Examine whether the family atmosphere is related to the students' home-based learning effect. Spearman Rank Correlation was conducted on "whether family conflicts occur during home-based learning" and "student learning effect”. The results are shown in Table 4.

Table 4. Correlations

\begin{tabular}{|c|c|c|c|c|}
\hline & & & $\begin{array}{c}\text { Do you have any conflict } \\
\text { with your child about learn- } \\
\text { ing during home study? } \\
\text { (Compared with normal } \\
\text { off-line classes) }\end{array}$ & $\begin{array}{l}\text { Compared with offline learn- } \\
\text { ing, how does the child learn } \\
\text { under home-based learning }\end{array}$ \\
\hline \multirow{6}{*}{$\begin{array}{l}\text { Spearman's } \\
\text { rho }\end{array}$} & \multirow{3}{*}{$\begin{array}{l}\text { Do you have any conflict with } \\
\text { your child about learning dur- } \\
\text { ing home study? } \\
\text { (Compared with normal } \\
\text { off-line classes) }\end{array}$} & $\begin{array}{c}\text { Correlation } \\
\text { Coefficient }\end{array}$ & 1.000 & $0.373 * *$ \\
\hline & & Sig. (2-tailed) & . & 0.000 \\
\hline & & $\mathrm{N}$ & 538 & 538 \\
\hline & \multirow{3}{*}{$\begin{array}{l}\text { Compared with offline learn- } \\
\text { ing, how does the child learn } \\
\text { under home-based learning }\end{array}$} & $\begin{array}{c}\text { Correlation } \\
\text { Coefficient }\end{array}$ & $0.373 * *$ & 1.000 \\
\hline & & Sig. (2-tailed) & 0.000 & . \\
\hline & & $\mathrm{N}$ & 538 & 538 \\
\hline
\end{tabular}

**. Correlation is significant at the 0.01 level (2-tailed).

The results show that there is a significant correlation between conflicts between parents and children and children's learning decline $(\mathrm{P}=.00<0.05)$. The correlation coefficient is 0.373 . The higher the frequency of conflicts between parents and children, the worse the children's home-based learning effect will be, indicating that family atmosphere has a very serious impact on children's learning.

Examine the correlation between parents' other ability cultivation and students' home-based learning effect. Based on the students' questionnaire, Spearman Rank Correlation was conducted on "whether parents pay attention to other ability cultivation during home-based learning" and "students' learning effect". The results are shown in Table 5.

The results showed that there was a significant positive correlation between parents' emphasis on students' ability cultivation in other aspects and students' home-based learning effect $(\mathrm{P}=.026<0.05)$, and the correlation coefficient was 0.086. The result shows that parents can improve students' learning ability during home life. 
Table 5. Correlations

\begin{tabular}{|c|c|c|c|c|}
\hline & & & $\begin{array}{l}\text { Do your parents value your devel- } \\
\text { opment in addition to learning? (For } \\
\text { example, practical ability, ideologi- } \\
\text { cal and moral education, cognition of } \\
\text { social and current affairs and news, } \\
\text { etc.) }\end{array}$ & $\begin{array}{l}\text { Do you get better } \\
\text { grades when you } \\
\text { study at home } \\
\text { compared to offline } \\
\text { learning }\end{array}$ \\
\hline \multirow{6}{*}{$\begin{array}{c}\text { Spearman's } \\
\text { rho }\end{array}$} & \multirow{3}{*}{$\begin{array}{l}\text { Do your parents value your devel- } \\
\text { opment in addition to learning? (For } \\
\text { example, practical ability, ideologi- } \\
\text { cal and moral education, cognition of } \\
\text { social and current affairs and news, } \\
\text { etc.) }\end{array}$} & $\begin{array}{l}\text { Correlation } \\
\text { Coefficient }\end{array}$ & 1.000 & $0.086^{*}$ \\
\hline & & $\begin{array}{c}\text { Sig. } \\
\text { (2-tailed) }\end{array}$ & . & 0.026 \\
\hline & & $\mathrm{N}$ & 673 & 673 \\
\hline & \multirow{3}{*}{$\begin{array}{l}\text { Do you get better grades when you } \\
\text { study at home compared to offline } \\
\text { learning }\end{array}$} & $\begin{array}{l}\text { Correlation } \\
\text { Coefficient }\end{array}$ & $0.086^{*}$ & 1.000 \\
\hline & & Sig. (2-tailed) & 0.026 & . \\
\hline & & $\mathrm{N}$ & 673 & 673 \\
\hline
\end{tabular}

*. Correlation is significant at the 0.05 level (2-tailed).

\section{Analysis and Reconstruction of the Traditional Instructional System}

The results of the questionnaire showed that only $16.91 \%$ of the parents surveyed said that even conflicts with their children would not affect their daily communication with their children. $6.88 \%$ of the surveyed parents had no anxiety or anxiety during the home-based study period. The data show that during the period of home-based learning, family conflicts will occur in most families, and parents' fidgety mood is easy to produce, which will have a bad influence on the family atmosphere. In terms of educational resources, the student questionnaire shows that $99.26 \%$ of students need to use electronic devices such as mobile phones, computers and tablets when they study at home (as shown in Figure 1), and $89.3 \%$ of students use electronic devices provided by their elders (as shown in Figure 2), which has a high demand for the amount of family hardware.67.61\% of the students indicated that they would actively seek help from their parents when encountering problems with schoolwork (see Figure 3).

Family participation for students of learning that occupy the home is greatly improved, the traditional instructional system problems emerging gradually, teachers, students, teaching resources and teaching media between the interactions between the four elements is not able to fully sum up the students' learning behavior, family and technology should be as important elements involved in the formation of the teaching system.

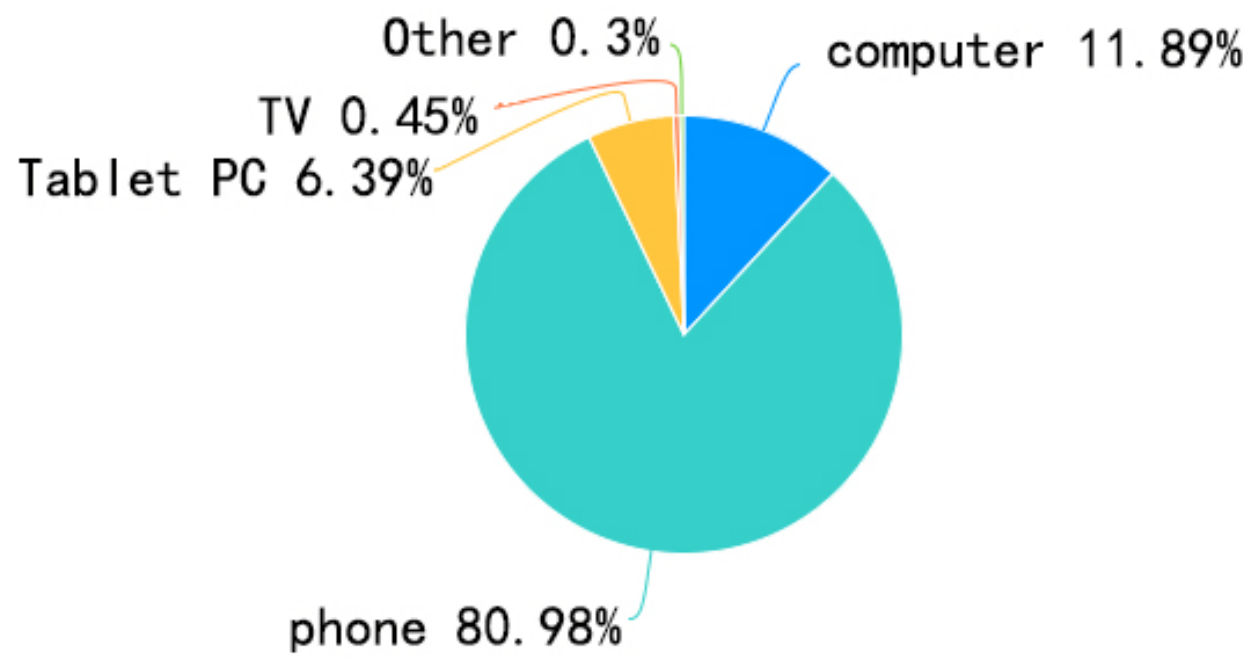

Figure 1. Student learning media. 


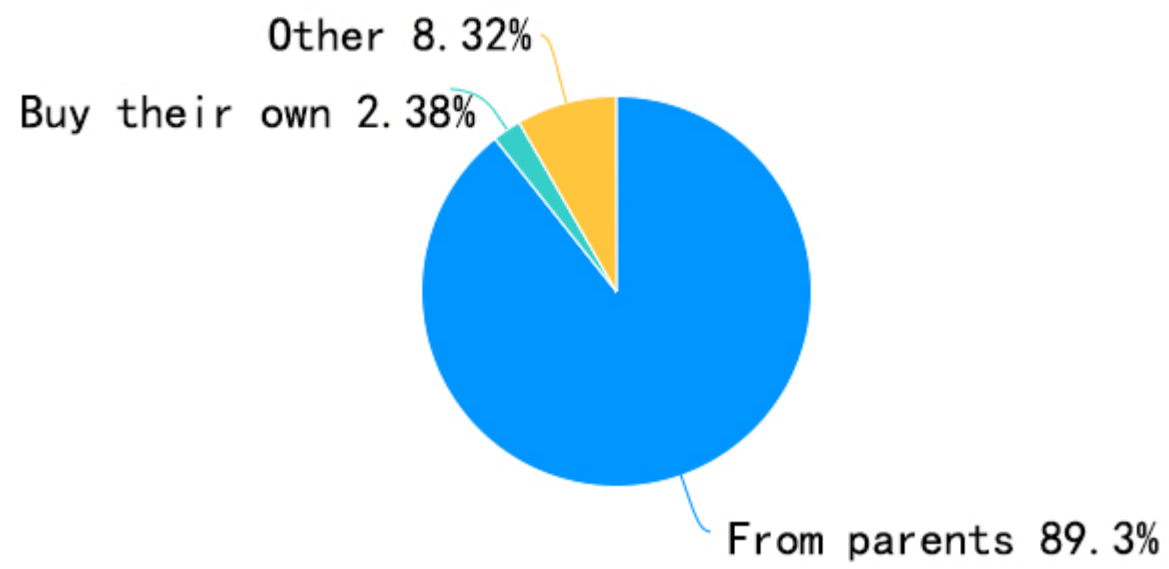

Figure 2. Supplier of electronic devices to learners.

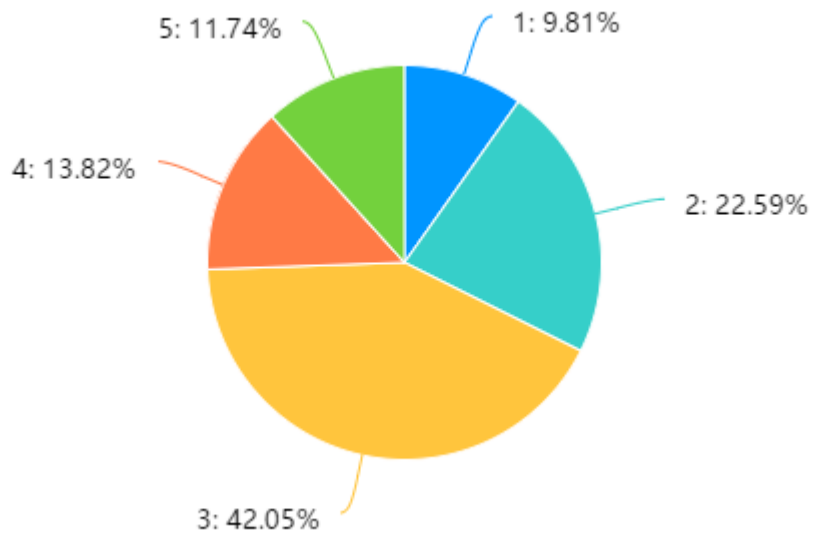

Figure 3. Probability of students asking parents for help with academic problems.

\subsection{Changes of the Traditional Four Elements in the Home-based Learning Environment}

Teaching content, teaching media, teachers, and students are the four basic elements of the instructional system, which are all affected to a certain extent under the wave of home-based learning. Teachers should familiarize themselves with the use of online teaching platform in the shortest time, adapt to the changes in teaching methods, design suitable teaching plans for online teaching, screen out appropriate resources and materials for students, and guide students to conduct online independent learning. The student-centered trend is more obvious. As students learn at home, they have to accept the change of learning style, and their former teachers and classmates have become a screen. From the point of view of various forms of home-based learning, students should not only receive school education, but also have family education to cultivate, improve life skills, cultivate independent personality, and promote the all-round development of morality, intelligence and body.

The teaching content has become richer, especially in the field of science education. Science education advocates students' learning in the real situation. During home-based study, students are not only encouraged to learn knowledge from books, but also encouraged to carry out research topics closely related to real life. They are guided by real life problems, analyze real data, and get operable results. The students had a deep understanding of the specific situation of the country, had a deeper understanding of the epidemic situation, and greatly improved their scientific literacy and scientific thinking ability.

Teaching media form becoming more diverse, the traditional teaching is mainly based on the blackboard, the blackboard writing as the main teaching media, teachers for oral interpretation of the knowledge to teach students, is now mainly by means of the Internet computer, phone, TV and other multimedia to implement the education teaching, teacher upload course video or online real-time lectures, students learn by watch the course video or video playback. In 
family education, students practice by themselves, through various forms of learning, exercise life skills, and sublimate the parent-child relationship between parents.

\subsection{A Teaching System that Incorporates Technology and Family Elements}

The teaching system under the technical support. In the instructional system under the home-based learning environment, the technical factors are mainly reflected in the online independent learning of students under the guidance of teachers, the online independent learning of students and the large-scale learning resources. There are network teaching platform system, online evaluation system and so on (Ding, 2011). Nowadays, there are various kinds of educational and teaching software with different advantages and functions. Teachers choose appropriate network platforms according to the content and characteristics of the courses they teach and upload their teaching courseware to the platforms. This involves a number of technical links. If the course is uploaded and recorded, the teacher should select a screen recording software with clear recording and picture quality and a simple and operable video editing software during the course of recording the course. If an excellent course video with high page view is uploaded, teachers need to find relevant resources in a secure and reliable search engine with abundant resources.

When students study online under the condition of complete autonomy, they will choose a network platform that meets their learning interests. When studying on the platform, students need to complete the tasks of answering questions, submitting homework and repeatedly watching courseware. The backstage operation of the platform needs to ensure its stability and simplicity of operation.

Technology makes resource sharing possible, and students from all over the world can see what they are interested in through the Internet platform. In recent years, MOOC, flipped classroom and other new classroom forms are all based on the achievements supported by computer technology. For example, excellent teachers record videos and upload them to the MOOC platform. Students from all over the world can apply for study and get credits after completing the corresponding tests. Especially for schools in backward areas, the advantage of information technology is more prominent, which makes up for the weakness of teachers. Students can feel the high-quality classroom through a computer, learn the most cutting-edge knowledge content in the field, broaden their horizon and expand their thinking.

The teaching system under family support. In the instructional system, the participation of family factors is mainly reflected in the online learning of students under the supervision of parents and family education. Parents create a good learning environment for students' online learning. In home-based learning, due to the change of online teaching methods and home-based teaching scenes, teachers assume less responsibility and obligation in the previous teaching course forms, and more responsibilities are transferred to parents. Parents play a role as a link, link the school teachers, guide their children's teaching. The results of the questionnaire showed that for k-12 students, parents were needed to help them with online learning at home. Especially for students in primary school, due to the characteristics of their cognitive ability and physical and mental health development, parents need to supervise and guide them to study for a longer time.

Online learning for a network of high strength makes for parents to participate in the school education teaching work in higher demand, parent assumes the role of "managing the students", also should realize their own role and the limitation of the family education, family education and school education, the relationship between the family education make reasonable positioning, and actively cooperate with school, in the form of parent-school cooperative escort for the growth of the students. Participate in the discussion of school teaching work, and put forward suggestions on school teaching arrangement from the perspective of parents, so as to achieve the goal of education. The research team led by Song Lingqing of China Audio-visual Education Center proposed a "teacher-parent-student" community framework model to realize the sustainable development of home-based learning. This framework model focuses on the role of parents in students' home-based learning process, and takes "teacher-parent-student" tripartite collaboration as the core, reflecting the dynamic relationship among various factors (Song, 2020).

In family education, the family is the leading role, which also determines the content, mode and method of education, and determines its educational object, educational space, educational content and educational method (Gao, 2020). Different from school education, family education should not only attach importance to children's curriculum learning, but also pay more attention to children's ideological and moral character, mental health, interest and hobby cultivation, good behavior and so on. The epidemic has created an opportunity for parents and children to get along for a long time. By setting an example, parents can teach their children some life skills and conduct family experiments, so that their children can use the abstract knowledge they have learned in class to explore together with their children in real life situations. Combine science with life, stimulate children's interest in learning, increase their learning motivation, feel the charm of scientific knowledge. Frequent and in-depth communication with children is conducive to the establishment of a good outlook on life, values. Implementation of family life education (FLE) can positively influence individ- 
ual and family well-being by helping families to help themselves (Carol, 2020).

A new frame diagram. Based on the actual situation of large-scale home-based learning, the author adds two elements of technology and family into the new teaching system. The new frame diagram is shown in Figure 4.

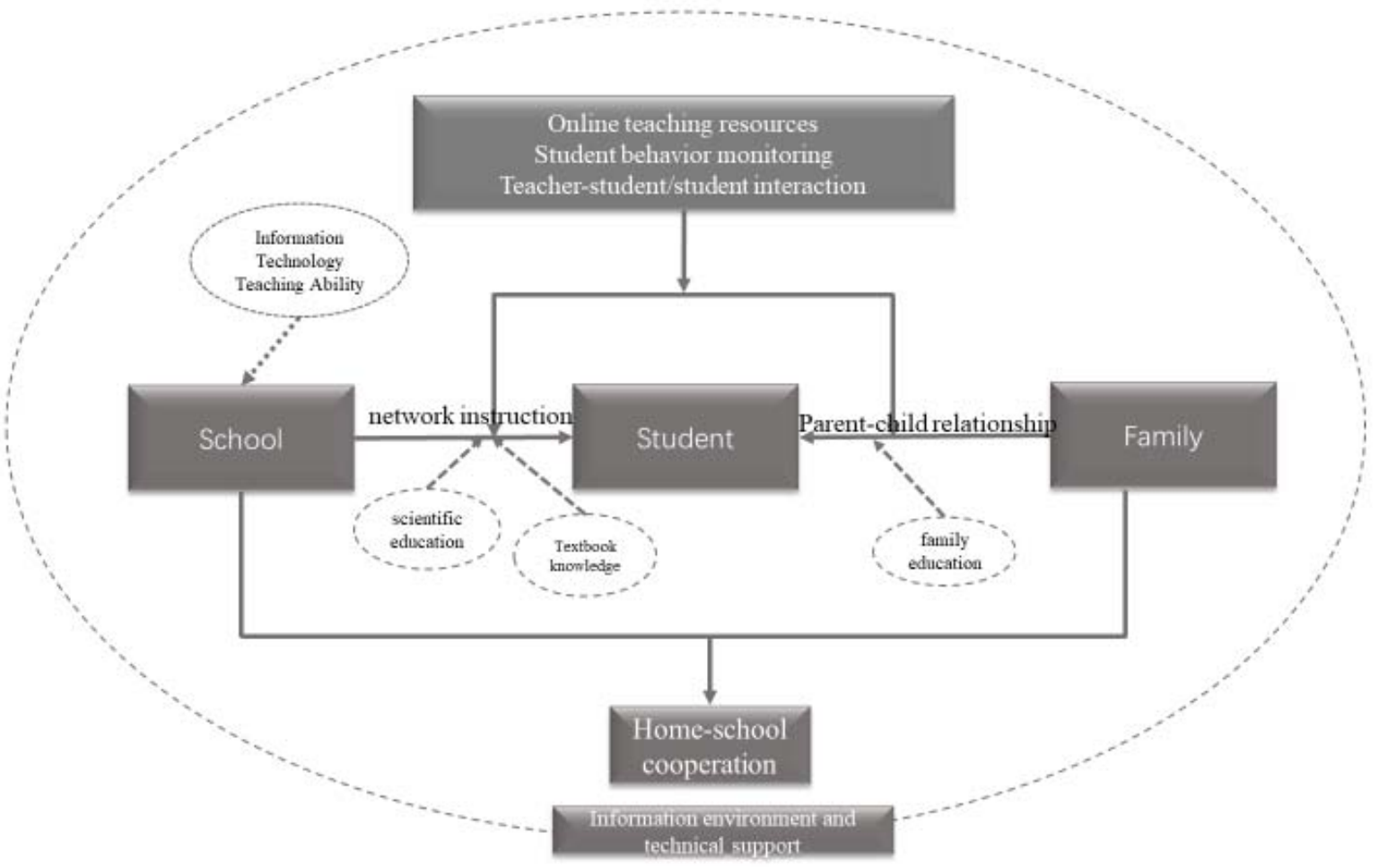

Figure 4. The new framework of teaching system under the condition of home-based learning.

\section{Suggestions on the Development of Home-School Linkage Teaching System}

\subsection{Students}

As the learning subject, students are mainly faced with online learning guided by teachers and family education in the home-based learning environment. The improvement of autonomous learning ability is an important guarantee to improve the effect of home-based learning. The results of the questionnaire from The Chinese Institute of Education Policy of Beijing Normal University show that "conscientiousness and self-discipline are important factors affecting home-based learning and online learning”. Develop good study habits, regular work and rest, make study schedule, and conscientiously complete the study content assigned by teachers. In the learning process, I have clear and clear subjective intentions for my own learning, monitor my own learning progress and learning effect, change my own learning strategies, and improve the learning effect. At the same time in a large number of extracurricular resources to choose their own interested content to study, develop their own expertise and hobbies. However, the improvement of autonomous learning ability requires students to have high self-drive (Song, 2020), self-directed learning ability and the ability to filter information. However, due to the lack of effective guidance, students often fall into trouble and waste time. Thus, students' independent learning depends more on teachers' professional guidance and parents' supervision and guidance.

In the long-term home life, students should also improve their life skills, such as housework, dealing with people and receiving guests, etc. Spend more time with your parents, strengthen communication, and enhance your understanding of each other. When the conditions permit, we should complete some scientific experiments together with our parents, so as to activate the family atmosphere and improve our own scientific literacy.

\subsection{Teachers}

Teachers are the organizers of online teaching, and improving information technology teaching skills is one of the conditions to ensure normal teaching. Teachers need to choose from a large number of resources, and modify and im- 
prove the relevant teaching design according to the characteristics of online teaching and the teaching environment of home-based learning. Network teaching and traditional teaching, the teacher should be timely guidance with students, give full play to students' learning autonomy, consciously train and cultivate the students' learning autonomy and creativity, inspire and guide the students' personality, promote students' learning interest, effectively promote students' ability in exploring, learning ability, and constantly improve and enhance the ability to solve the problem (Su, 2020). In addition to guiding students' online learning, teachers should have close communication with parents, put forward the hardware requirements of home-based learning to parents, ask them to cooperate with the school and teachers to do a good job of supervision, understand students' home-based learning, and periodically report students' attendance and homework quality to parents.

Teachers should pay attention to the role of home-school interaction of teaching data. Online teaching produces a lot of learning data. Teachers use these data to guide parents to supervise at home, help students learn correctly and improve their learning ability. For students in poor and remote areas, the situation that their parents go out to work leads to little communication between parents and students, which has a certain impact on children's self-development (Xiao, 2020). Therefore, teachers should focus on the students to reduce their sense of helplessness and loneliness (Hu, 2020).

\subsection{Family}

Family is the core element of home-based learning, and a comfortable family atmosphere is an important basis for ensuring good effects of home-based learning for children. Parents also need to cooperate closely with schools and choose appropriate teaching methods based on students' physical and mental characteristics to improve students' independent learning ability. At the same time, we should actively participate in the school's characteristic school-based courses, carry out family education, enrich students' home-based learning and life experience (Hu, 2020), and enhance parent-child relationship. According to the questionnaire survey of parents, $86.9 \%$ of parents actively cooperate with teachers in teaching when their children are at home, and $67.1 \%$ of parents believe that timely communication should be conducted with the school. Parents need to improve their information literacy, take the initiative to learn the use of some electronic devices, and participate in the parent-oriented professional live lectures on information literacy education organized by the school (Hu, 2020), so as to keep pace with The Times and master the learning tools of the intelligent age.

Parents should also play their own active role, make use of their own career characteristics, carry out career education, help students to enhance the understanding of the nature of different careers, cultivate students' sense of mission and responsibility. If parents are unable to stay at home with their children for a long time, they should keep in touch with their children online and pay attention to their children's learning and growth. Parents can exchange their children's home-based learning and guidance experience with other parents through online platforms to create a good atmosphere of mutual assistance. The implementation of teacher-parent-student tripartite collaboration is the core and key of home-based learning and promotes efficient online teaching.

\subsection{Teaching Resources}

The questionnaire survey shows that about $63 \%$ of families have more than one child who needs online learning, which is a huge challenge for the number of electronic devices in the family. Relevant education departments should pay attention to the allocation of teaching media resources and provide appropriate help within the allowed scope, which can be financial help or appeal to the public to contribute idle electronic devices at home to help poor families. Education companies should focus on strengthening and enriching the functions of the technology platform to meet the teaching needs of teachers' live-streaming courses, interaction with students, collection and correction of homework, so as to get closer to the actual effect of offline teaching.

\subsection{Teaching Content}

Students' learning content during home study should not be limited to textbook knowledge, but should also include family education and science education. For example, during the outbreak of the epidemic, biology teachers can disrupt the order of the original textbook content, combine it with reality, and lead students to study the nature of the new coronavirus and the body's resistance mechanism, so as to learn the process mechanism of human body specific immunity. Family education and family education is a moral education beyond textbook knowledge. It focuses on teaching rather than education. It is not limited by time and space. It aims to cultivate students' good moral character. Parents should transmit correct information to their children in a subtle way. Values, teach them the principles of life, and set a good example. 


\section{Conclusions}

Education has a unique and essential role to play in preparing us to become future-fit and future-creative (Smitsman, 2019). However, so far, it has not even come close to fulfilling this role (Smitsman, 2020). The precondition of the reconstruction of the instructional system is the analysis of its various elements. Teachers, students, teaching media, and teaching content are the four elements of the traditional instructional system. The four elements interact with each other and support the teaching development of school education. Although the family also bears some social responsibility, but not as a decisive existence. But home learning makes the teaching methods, teaching environment, great changes have taken place in the student's learning environment of family, make online teaching school education need depend on the degree of information network technology improved, teachers for students' monitoring strength is reduced, the parents become the link between students and schools, parents also is the core of family education at the same time. In order to achieve the goal of education in the home-based learning environment, parents and technology must be integrated into the teaching system and become the indispensable two links in the instructional system.

With the addition of family and technical elements, the learning system is more effective, covers a wider range of education types, and applies to more student groups. It includes both school education and family education, and can have different educational stresses on students under different conditions. For example, in areas with poor Internet conditions, it is difficult to realize online teaching, so teachers can cooperate with parents of students, give parents some guidance on teaching methods, combine textbook knowledge with life practice, and promote students' mastery of subject knowledge. The construction of a new teaching system can remind families, enterprises, schools and other groups of students family education, so as to modify the teaching strategy, innovative software capabilities, to enhance the school contact, increasing the participation of parents for children to grow up process, to improve the current situation of China's long-term lack of family education, improve the study of ecological system imbalance problem.

\section{References}

Darling, Carol A., Dawn Cassidy, and Marsha Rehm. (2020). The Foundations of Family Life Education Model: Understanding the Field. Family relations, 69(3), pp. 427-441.

Deng, X. Q. and Du, C. X. (2009). Ecology of education has been studied for twenty years. Theory and Practice of Education, 29(13): 12-16.

Ding, W. Z. and Qian, X. L. (2011). Evaluation of teaching System supported by technology: Deconstruction and Reconstruction. E-education Research, (09): 16-19+32.

Gao, S. G. (2020a). Lack of theory and reconstruction of confidence in Chinese family Education research. Research in Educational Development, 40(02): 9-17.

Gao, S. G. (2020b). Practice exploration and Reform of home-based learning-from the Great Epidemic to the Great Easy. Educational Science Research, (07): 5-11.

Guidance for COVID-19 prevention and control in schools. https://www.unicef.cn.

Hecht, M. (2020). Relational processes between people and place: Understanding environmental interest and identity through a learning ecosystem lens. Environmental Education Research, 26(7): 1060-1061.

Home-based study is an emergency method under the epidemic situation, and also brings opportunities to the reform of primary and secondary education! These are the implications. https://xw.qq.com.

Hu, X. Y., Lin, Z. R., and Liang, J. Q. (2020). Is home-school collaboration ready for online teaching under the epidemic? Modern Distance Education, (03): 3-8.

International Home Education to Continue Offering Tutorship to Students via Online Classes amid the COVID-19 Threat. (2020).

Liang, L. M., Cai, J. D., and Geng, Q. Q. (2020). Online Teaching in Primary and Secondary Schools under the Epidemic: Reality, Improvement Strategies and Future Reconstruction-An analysis based on the learning perspective. E-education Research, 41(05): 5-11.

Mu, S. and Wang, Y. N. (2020). Change “danger" to "Chance”: How to move to system online teaching in Emergency on-line teaching. Modern Distance Education Research, 32(03): 22-29.

Palm, Glen F. (1999). Ethical Thinking and Practice for Parent \& Family Educators. Faculty Publications. 18, https://repository.stcloudstate.edu/cfs_facpubs/18.

Smitsman, A. and Smitsman, A. W. (2019). The future-creative human-exploring evolutionary learning.

Smitsman, A., Laszlo, A., and Luksha, P. (2020). Evolutionary Learning Ecosystems for thrivable Futures: Crafting and Curating the Conditions for Future-Fit Education. World Futures, 76(4): 214-239. 
Song, L. Q. and Xu, L. (2020). Construction of students' home-based learning style, learning content and learning mode during the epidemic period. E-education Research, 41(05): 18-26.

Song, L. Q., Xu, L., and Li, Y. X. (2020). Accurate online teaching + home-based learning mode: A way to improve the learning quality of students in the epidemic period. China Educational Technology, (03): 114-122. http://kns.cnki.net/kcms/detail/ 11.3792.G4.20200310.1628.032.html.

Study at home: “A Great educational experiment”. (2020). http://www.360doc.com.

Su, Y. N. (2020). To improve students' learning autonomy in biology teaching in junior middle school. China Educational Technology \& Equipment, (17): 119-120.

Wu, S. Y. (2015). Research on the Model of online education embedded in the education ecosystem. Higher Education Exploration, (10): 20-24.

Xiao, X. L. (2020). A Case Study on The Influence of Family Education on Rural Children's Self-Concept.

Yu, S. Q. and Wang, H. M. (2020). How to better organize online learning in extreme environments such as epidemics. China Educational Technology, (05): 6-14+33.

Zhu, Z. T., Guo, S. Q., Wu, D., and Liu, S. Y. (2020). The policy interpretation, key issues and countermeasures of "Suspension of classes without suspension”. China Educational Technology, (04): 1-7. 